\title{
PROBLEMATIKA METODOLOGI HUKUM ISLAM GHAIRU MAHDHAH DI INDONESIA
}

\author{
Muhaimin \\ Kementerian Agama Republik Indonesia \\ Email:muhaimin.kemenag@gmail.com
}

\begin{abstract}
This article aims to find essays (ontologies) that are able to answer the problems of implementing the Islamic law of Ghairu Mahdhah in Indonesia. The study of this article is included in the literature review using a dialectical reasoning approach between text (nas) and context (empiricity) and is guided by maqasid al-sharia so that the legal product does not deviate from the essence (ontology) of Islamic law itself. The results of this study indicate that the dominance of the bayani epistemology which prioritizes text (nas) in understanding the sources of Islamic law and its legal products are normativeidealistic (das sollen) are very much felt in Indonesia today. Legal products of this kind are ideal (das sollen) often leave empirical-sociological dynamics and tend to give birth to exclusive, emotional and truth claims. The essence of this religious attitude is really needed, but its implementation often ignores the realities of society (das sein).
\end{abstract}

Keywords: Problematics, Islamic Law Methodology, Ghairu Mahdhah

\begin{abstract}
Abstrak
Artikel ini bertujuan untuk menemukan esesnsi (ontologi) yang mampu menjawab problematika implementasi hukum Islam Ghairu Mahdhah di Indonesia. Kajian artikel ini termasuk dalam kajian kepustakaan dengan menggunakan pendekatan nalar dialektika antara teks (naṣ) dengan konteks (empirisitas) dan dipandu dengan maqasid al-syariah agar produk hukumnya tidak menyimpang dari esensi (ontologi) hukum Islam itu sendiri. Hasil kajian ini menunjukkan bahwa dominasi epistemologi bayani yang lebih mengedepankan teks (naș) dalam memahami sumber hukum Islam dan produk hukumnya bersifat normatif-idealistik (das sollen) sangat dirasakan di Indonesia saat ini. Produk hukum semacam ini bersifat ideal (das sollen) seringkali meninggalkan dinamika empiris-sosiologis dan cenderung melahirkan sikap eksklusif, emosional dan truth claim. Inti sikap religius ini memang sangat dibutuhkan, namun seringkali implementasinya mengabaikan realitas masyarakat (das sein).
\end{abstract}

Kata Kunci: Problematika, Metodologi Hukum Islam, Ghairu Mahdhah 


\section{PENDAHULUAN}

Dalam perspektif teologis, al-Qur'an merupakan firman Allah SWT yang di dalamnya terkandung nilai dan ajaran yang bersifat Ilahiyah yang dikodifikasikan dalam sebuah kitab dan karena itu sekaligus bersifat transenden. Ajaran al-Qur'an yang telah mengejawantah secara empirissosiologis merupakan fenomena peradaban, kultural dan realitas sosioreligius dalam kehidupan manusia. Namun demikian ajaran empirissosiologis tersebut ada yang bergeser menjadi entitas sejumlah doktrin teologis dan diberlakukan secara universal tidak terikat oleh situasi dinamika ruang dan waktu (Azra, 1996: 1).

Pada mulanya, aspek teologis dari agama itu direspon oleh manusia, dan melahirkan konsep-konsep dasar (grand concept) dengan berbagai dimensi ajarannya. Diantaranya adalah apa yang disebut Azyumardi Azra dengan "pola-pola pandangan yang mendunia (weltanschauung) atau "konsep-konsep al-Qur'an", atau "moral values", pada dataran meta-konsept. Aspek ini mempunyai wujud ekstra-historis yang transendental dan datarannya dalam satu waktu dalam sejarah tidaklah membatasi dampak praktisnya atau bahkan mungkin dikatakan, maknanya. Sementara itu untuk kategori norma historis praktis yang ditampilkan oleh suatu masyarakat tertentu, pada masa tertentu, terbatas cakupannya dalam konteks sosio-historis dalam ruang waktu tertentu (Fazlurrahman, 1983: 6).

Proses metodologis tersebut oleh sebagian fuqaha seringkali dinegasikan dan memposisikan sumber ajaran berada pada entitas historis-praktis dan atau mendudukkan entitas historis-praktis sebagai doktrin teologis. Memang terdapat ayat-ayat yang bersifat tafșili (rinci) yang memungkinkan untuk diimplementasikan dalam kehidupan praktis, akan tetapi ketika berhadapan dengan dinamika sosio-religius masyarakat alih-alih mencoba memahami esensi pesan transendental ayat-ayat tersebut, yang terjadi kemudian meninggalkan sama sekali. Seperti ayatayat al-Qur'an yang mengatur waris dan hukuman potong tangan bagi pencuri, telah dipahami sebagai norma hukum dan terlepas dari munasabah dimensi keberagamaan yang lain (aqidah dan akhlak) serta terlepas dari konteks sosio-religius masyarakat ketika ayat-ayat tersebut dipahami.

Dalam konteks yang lebih utuh, konseptualisasi ajaran hukum Islam yang dipelajari dari sumbernya tersebut tidak dilepaskan secara parsial dari bagian beragama yang dibangun dari tiga pilar yaitu akidah, akhlak dan shari'ah (Khalaf, 1972: 8). Dapat dikatakan bahwa perumusan, pembentukan dan pengembangan norma hukum Islam di Indonesia telah tereduksi dari yang seharusnya menjadi bagian beragama yang dibangun dari tiga pilartersebut.Agama Islam itu sendiri diturunkan oleh Allāh agar terwujud rahmat bagi kehidupan di dunia ini, tetapi tujuan itu lebih 
dipahami dalam perspektif normatif dan rigit yang kemudian menjadi acuan sistem hukum yang berlaku di Indonesia. Pemahaman reduksionis norma hukum Islam tersebut selaras dengan peradaban dunia dan dominasi perkembangan metodologi keilmuan dengan paradigma positivisme dan rasionalisme yang berdampak wujudnya pluralisasi ilmuilmu sosial dan kemanusiaan (Muhadjir, 2007: 1).

Dampak dari reduksi tersebut terlihat pada bangunan ontologi (the body of knowledge) hukum Islam yang terkikis dari aspek teologis dan humanis (aqidah dan akhlak) yang sedari awal menjadi pondasi beragama. Dimensi teologis dan humanis sebagai kekuatan internal (internal power) hukum Islam nyaris tidak tampak dalam menyelesaikan masalah sosial keagamaan. Sebagaimana dikatakan Jassir Auda bahwa perumusan hukum Islam yang terlepas dari maqasid al-syariah maka produk hukumnya tidak menghadirkan maslahah ammah dalam pluralisme kehidupan bermasyarakat dan berbangsa (Auda, 2008: 29).

\section{METODE PENELITIAN}

Artkel ini merupakan jenis penelitian kepustakaan dengan menggunakan metode pendekatan nalar dialektika antara teks (naș) dengan konteks (empirisitas). Dalam penelitian kepustakaan, metode yang digunakan dalam mengumpulkan data penelitian adalah berupa data-data kepustakaan yang telah dipilih, dicari, disajikan dan dianalisis. Sumber data dalam penelitian ini berupaya mencari data-data kepustakaan yang substansinya membutuhkan tindakan pengolahan secara teoretis dan filosofis (Muhadjir, 1998: 159). Adapun sumber data yang digunakan adalah data primer dan data sekunder. Data primer berupa kitab-kitab fiqih dan kitab ushul fiqih. Sedangkan data sekunder berupa buku-buku, artikel, majalah dan lain-lain.

Metode analisis data yang digunakan adalah analisis diskriptif kualitatif. Dengan analisis diskriptif kualitatif ini akan diperoleh suatu gambaran dan keterangan secara obyektif, sistematis, kritis, dan jelas mengenai problematika metodologi hukum Islam ghairu mahdhah di Indonesia.

\section{PEMBAHASAN}

\section{Epistemologi Hukum Islam}

Para fuqahā'sepakat bahwa hukum Islam telah mengatur seluruh bidang ibadah baik ibadah mahdah maupun ibadah mu'āmalah. Dalam bidang ibadah mahdah yang dikhususkan kepada umat Islam pelaksanaannya telah diatur melalui Sunnah Rasul, bersifat $t a^{\prime} a b b u d \bar{\imath}$ atau ghairu ma'qulah al-ma'nā. Sedang bidang muamalah yang berlaku umum bentuk pelaksanaannya bersifat longgar, sosiologis dan $t a^{\prime} a q q u l i ̄$ atau $m a^{\prime} q u \bar{l} l a h$ al-ma'nā (Djamil, 1997: 52). Dalam bidang ini para ulama diberi 
peluang untuk berijtihad dalam mengembangkan dan menerapkan hukum Islam untuk mewujudkan mașlaḥah khāsșh (individual) maupun maṣlaḥah āmmah (umum) dalam bingkai maqāṣid al-sharī'ah (al-Ghazali, 2000: 286).

Ragam metodologi berijtihad dalam konseptualisasi mașlahah dalam bingkai maqāșid al-sharīah mengiringi ragam metodologi konseptualisasi hukum Islam yang mengalami dinamika keilmuan selaras dengan peradaban masyarakat (Schatch, 1964: 28). Pada masa Nabi, tidak dibutuhkan metodologi dalam memahami sumber hukum Islam karena masih mendapatkan bimbingan langsung dari beliau. Setelah Islam berkembang dan umat Islam tersebar ke berbagai wilayah, sumber otoritatif tersebut telah terhenti tidak mampu memenuhi kebutuhan praktis yang terus mengalami perkembangan, oleh karena itu para fuqaha kemudian berijtihad untuk memahami sumber hukum Islam. Hal tersebut tampak pada perkembangan ilmu fiqh abad ke-2 hijriyah yang telah dilengkapi ilmu ushul fiqih untuk merespon masalah-masalah dalam beragama yang berkembang semakin kompleks dan rumit (Praja, 1991: 6).

Pada periode pembentukan hukum Islam, para fuqahä'Sunni terbagi ke dalam dua kecenderungan dalam memahami sumber hukum dan pengembangan hukum Islam. Pertama, fuqahä' Sunni ahl al-hadith di Hijaz dengan tokohnya Imam Mālik ibn Anas (95-179 H), yang kedua fuqahä'Sunni ahl al-ra'y di Iraq dengan tokohnya Imam Abū Hanīfah (80$150 \mathrm{H}$ ) (Shahrodi, 2008: 115). Yang pertama cenderung mempertahakan dominasi teks (nas )sekalipun untuk itu dilakukan statisasi teks (taqdìm alnaș'alā al-mașlaḥah), yang kedua lebih mengedepankan entitas empiris dunia manusia sekalipun di dalamnya terjadi distorsi, gradasi, dan reduksi terhadap keutuhan teks itu (taqdìm al-maṣlahah 'alā al-naș wa alijmā').

Kecenderungan kelompok pertama banyak bertumpu pada metode qiyās di samping metode khusus masing-masing imam, seperti maslahah mursalah, 'urf dan istișlāh, dalam menggali sumber hukum dan pengembangan hukum Islam. Kelompok ini memandang akal tidak dapat memperoleh pengetahuan, kecuali ia disandarkan kepada teks (naș), menjadikan tradisi berpikirnya dikenal dengan pola berpikir literalistik. Untuk mendapatkan pengetahuan, mereka menempuh dua cara, pertama melalui zahir-nyanaș; kedua memposisikan akal sebagai alat (tool) untuk mengungkap makna dibalik teks (Muslih, 2004: 62). Pola berpikir semacam ini tampak pada posisi simpulan dari hasil metode qiyās yang masih dikaitkan dengan hukm al-aṣl-nya, satu peringkat di bawah simpulan yang diperoleh melalui metode $i j m \bar{a}$ ' sahabat (Khalaf, 1972: 15).

Sedangkan kecenderungan kelompok kedua dalam menghadapi dan menyelesaikan berbagai permasalahan yang belum ada dalilnya bertumpu pada metode istiḥsān, istiṣlāh,istidlāl, dan 'urf. Pemanfaatan akal 
dalam penerapan metode-metode ini tampak lebih dominan dan terlebih untuk memperoleh simpulan hukum dari teks yang mesti diuji melalui pengalaman empiris (Muslih, 2004: 67). Contohnya adalah simpulan hukum yang diperoleh melalui penerapan metode istihsān.

Ketika Islam mulai menyebar ke wilayah Timur Dekat (Irak dan sekitarnya) pada tahun $641 \mathrm{M}$, di wilayah itu sedang giat-giatnya menerjemahkan, mempelajari dan memanfaatkan buku-buku dari Yunani, maka terjadilah penyerapan pengetahuan Yunani yang rasionalis ke dalam pengetahuan Islam. Hal ini tampak pada pola berpikir dan epistemologi hukum Islam dalam wujud tiga karakteristik pemikiran. Pertama, dogmatisme yang rasionalistik dan tradisionalistik; kedua, sufisme (tasawuf) dan ketiga rasionalisme (Qadir, 1991: 34). Kaum dogmatis dalam tradisi pemikiran Arab dikenal dengan paham mutakallimin, dalam konseptualisasi mașlaḥah dalam bingkai maqāșid alsharī'ah hukum Islam terlihat pada pemikiran dan metode ijtihad fuqaha $\bar{a}^{\prime}$ Sunni tradisionalis (pola berpikir Imam Mālik) maupun yang rasionalis (pola berpikir Imam Abū Hanīfah).

Imam Shafi' 1 (150-204 H) berupaya mensintesakan kecenderungan tradisionalis dan rasionalis dalam mengembangkan hukum Islam (Hallaq, 2005: ix). Upaya Imam Syafi'i ini pada mulanya kurang mendapatkan respon tetapi setelah abad sembilan menemukan momentumnya di tangan Ibn Suraīj al-Baghdadī (w. $306 \mathrm{H}$ ) dan murid-muridnya yaitu Abū Bakr al-Șairafī (w. 330 H), Abū Bakr al-Qaffal (w. 365 H) dan lain-lain.

Dalam perspektif sosiologi dapat dikatakan bahwa ontologi maṣlahah dalam bingkai maqāṣid al-sharī'ah hukum Islam sesungguhnya merupakan bagian dari dialektika keberagamaan umat Islam dalam merespon ajaran agama berhimpitan dengan dinamika peradaban Islam. Bentuk-bentuk peradaban Islam sangat terkait dengan budaya dan sosioreligius yang berkembang di lingkunganmasyarakat di mana umat Islam merespon ajaran Islam itu sendiri (Riyanto, 2009: 34). Oleh karena itu dimensi pengetahuan sebagai produk dialektika keberagamaan umat Islam dalam merespon ajaran agama masih bersifat subyektif (zan) dalam mentransendensikan diri atas realitas sosio-religius masyarakat di sekitarnya.

\section{Pergeseran Hukum Islam $\mathrm{Ta}^{\prime} a q q u l i$ kepada Hukum Islam $\mathrm{Ta}^{\prime}$ abbudi}

Bergesernya produk hasil ijtihad hukum Islam menjadi suatu doktrin ajaran keagamaan, menjadi bagian yang saling berkelindan dalam pengembanan hukum Islam di tengah dinamika sosio-religius masyarakat. Salah satu yang penyebab bergesernya hukum Islam menjadi suatu doktrin ajaran keagamaan adalah adanya proses institusionalisasi hukum oleh para pengikut madzhab tertentu yang diikuti dengan pola sosialisasi hukum Islam bernuansa fanatisme madzhab ( $\mathrm{Mu}^{\prime}$ alim dan 
Yusdani, 2005: 5). Dapat dikatakan bahwa sosialisasi hukum Islam yang berorientasi pada mașlahahjuz'iyyāt berimplikasi terhadap tidak hadirnya kemaslahatan atau manfaat hukum Islam dalam kehidupan publik.

Produk hukum yang berorientasi pada mașlahah juz'iyyāt menjadi salah satu sebab tergerusnya (reduksi) mașlahah 'āmmah yang seharusnya hadir di tengah penerapan hukum Islam. Reduksi mașlahah hukum Islam juga disebabkan bergesernya posisi produk hukum Islam yang terintegrasi dengan berbagai dimensi ajaran Islam, seperti aqidah, akhlak dan tasawuf menjadi suatu disiplin ilmu. Posisi produk hukum Islam masa awal sebagai bagian beragama, esensinya adalah religius dan berjalin berkelindan secara religius (Rahman, 1997: 91). Karakter produk hukum semacam ini ditandai adanya kekuatan internal (internal power) dan menghadirkan mașlahah 'āmmah karena tujuan praktis dari hukum Islam merupakan bagian dari konsep beragama yang berhubungan dengan tingkah laku individu dan sosial, baik spiritual, mental dan fisik (Rahman, 1997: 141).

Sampai akhir abad ke-2 H (8 M), syari'ah Islam masih terintegrasi dengan seluruh dimensi keagamaan. Terminologi syari'ah belum dikenal, karenanya Fazlur Rahman hampir selalu menyebutnya dengan al-din, yang tidak hanya merujuk kepada agama tetapi juga menyangkut hukum. Ruang lingkup terminologi syari'ah Islam secara bertahap menyempit, dan akhirnya terbatas hanya pada masalah-masalah hukum (figh), bahkan lebih sempit lagi, yaitu pada kumpulan produk hukum (yurisprodensi) (Hasan, 1994: 6).

Ketika dunia Islam mengalami kemunduran, dan mencapai puncaknya abad ke-9 hijriyah (15 M), hukum Islam dalam pengertian fiqh tersebut telah terelaborasi secara rinci dan para fuqah $\bar{a}^{\prime}$ berkesimpulan bahwa seluruh persoalan telah dibahas dan dijawab secara tuntas (Nasution, 1987: 14). Sementara peradaban di belahan dunia Barat (Eropa) setelah Napoleon menduduki Mesir (1798 M) mulai menunjukkan kemajuan yang ditandai munculnya berbagai disiplin keilmuan. Ilmuilmu Islam mengalami pluralisasi, lahir disiplin ilmu-ilmu Islam yang terkotak oleh obyek materia maupun obyek forma masing-masing ilmu, seperti ilmu tauhid, ilmu fiqh, ilmu tafsir dan lain-lain.

Hukum Islam yang telah menjadi suatu disiplin ilmu memiliki obyek materi dan obyek forma sendiri, dengan ragam paradigmanya. Hukum Islam semakin mendalam mengkaji obyeknya, tetapi secara perlahan terpisahkan dari konteks beragama. Inti beragama menjadi samar-samar, dimensi transendentalismenya semakin kabur oleh perdebatan dan perbedaan pendapat di kalangan umat Islam mengenai pemahaman dan penerapan hukum Islam (As-Asymawi, 2004: 24). 
Metode legislasi dan produk hukum dari para fuqahā' akhir abad kedua dan pertengahan abad ketiga hijriyah tersebut, kemudian diakomodasi dan diterapkan pada wilayah lain, yang berbeda karakteristiknya. Oleh masyarakat setempat, kemudian dibakukan dengan sistem perhubungan (sanad) dan dipegangi sebagai doktrin hukum (Mas'udi, 1999: 251). Hasil pemikiran dari para fuqah $\bar{a}$ ' tersebut disatukan oleh murid-murid, dengan menjaga identitas dan karakteristik madzhabnya, serta memposisikannya sebagai karya suci (transendentalis).

Keadaan di atas, mengingatkan pada sejarah ketika Herodotus menceritakan orang-orang Mesir yang negaranya telah runtuh dan terpasung oleh kepercayaan lama. Suatu ungkapan sejarah yang menggambarkan tabiat (watak) kemanusiaan yang selalu rindu kejayaan masa lalu, kemudian melebih-lebihkan dan mengagungkannya, karena menyaksikan masa sekarang yang penuh kekurangan. Sikap dan watak manusia tersebut dapat dikatakan menemukan signifikansi-legitimasinya, ketika umat Islam sedang mengalami kemunduran dan menyaksikan kemajuan di belahan dunia Barat, orang-orang Islam teringat kembali masa kejayaan yang pernah dialami. Mereka menolak meninggalkan berbagai ketetapan yang telah ditentukan oleh para ulama terdahulu dan tidak menyadari bahwa mereka telah hidup pada waktu dan tempat yang berbeda dari para ulama mereka. Permasalahan yang dihadapi umat Islam jauh berbeda dengan yang dihadapi para ulama masa lalu (Rahman, 1997: 140-165).

Pada dekade masa kemunduran tersebut, Islam masuk ke wilayah nusantara melalui para sufi yang lebih berorientasi dimensi asketissufistik (Fuad, 2005: 33). Paham sifisme yang esoterik dan mengutamakan kesalehan individual ikut membentuk karakteristik Islam Indonesia. Watak sufistik pada gilirannya bukan melahirkan fuqaha $\bar{a}^{\prime}$ tetapi tokoh sufi besar seperti Nuruddin al-Raniri (w. 1068 H/1658 M), Hamzah Fansuri (wafat kira-kira 1607 M), Abd al-Rauf al-Sinkili (w. 1105 H/1693 M), dan Walisongo di Jawa (Wahid, 2001: 110).

Tidak diragukan bahwa keberhasilan para da'i sufi dalam mensosialisasikan Islam di wilayah nusantara telah menunjukkan hasil yang mengagumkan. Ketangguhan Islam individual belum cukup mengikis tumbuh suburnya fanatisme madzhab di kalangan umat Islam dan produk hukumnya menjadi indikasi hukum Islam yang sedang kehilangan daya kekuatan (elan vital) dan daya kreatifitasnya. Dapat dikatakan bahwa institusi hukum Islam tidak menghadirkan mașlahahdi tengah kehidupan bermasyarakat dan berbangsa.

Kondisi tersebut ditunjang oleh karakteristik hukum Islam yang sedang mengalami keterputusan antar dimensi keberagamaan, pada gilirannya menjadi salah satu penyebab terjadinya kesenjangan antara ideal hukum dengan realitasnya. Jassir Auda menyatakan bahwa bentuk- 
bentuk pelanggaran hak asasi manusia, korupsi, persoalan ketidakadilan, peminggiran perempuan, bahkan terorisme banyak terjadi pada wilayah yang mayoritas berpenduduk muslim. Bukti-bukti itu berlawanan dengan hukum Islam yang mendorong terwujudnya keadilan, hidup produktif, humanis, spiritualis, clean government, persahabatan dan kehidupan yang demokratis.

NJ. Coulson juga berkesimpulan bahwa syari'ah (hukum Islam) yang telah tersusun secara sempurna dari para guru madzhab, kemudian dibukukan, diberi komentar (sharkh) yang pada umumnya memperkuat pendapat para guru. Maka hukum Islam menjadi statis dan bersifat kekal, mengapung bagaikan jiwa tanpa jasad, terpisah dari arus pergantian waktu, tampil sebagai hukum yang dicita-citakan, keabsahannya berlaku abadi dan masyarakat harus mengejar cita-cita itu (Coulson, 1964: 3). Hukum Islam telah menjadi "menara gading" dan masyarakat cukup puas memandang keindahannya.

Ali Shariati dalam teori sosiologinya menjelaskan mengenai proses dialektika kecenderungan budaya atau keagamaan masyarakat dari zaman ke zaman. Ketika arah dan tendensi masyarakat yang dibingkai suatu doktrin, maka budaya atau keagamaan masyarakat akan mengkristal menjadi kepercayaan atau ajaran yang baku (Syariati, 1983: 2). Pandangan Shariati ini menunjuk pada situasi ketika Islam mengalami suatu fase kemunduran (mulai abad ke-4 H sampai ke-7 H) dan muncul wacana 'tertutupnya pintu ijtihad.

S.H. Nasr berpendapat bahwa hukum Islam kurang responsip dalam menghadapi berbagai permasalahan kemasyarakatan, antara lain karena terkotak-kotaknya ajaran Islam. Terminologi dan batasan hukum Islam terlepas dari terminologi keberagamaan (Nasr, 1983: 66-68). Menurut Fazlur Rahman, karena hukum Islam telah bergeser dari yang semestinya ijtihädiyyah menjadi normatif-doktriner dan tidak ada peluang masuknya pemikiran. Hukum Islam dianggap telah lengkap dan dibakukan secara rinci dan rapi sebagai suatu doktrin, baik yang menyangkut bidang 'ibādah, mu'āmalah, munākahah, jināyah dan bidang dustüriyah.

Bergesernya posisi hukum Islam sebagai hasil pemikiran dari mașādir al-sharī'ah menjadi normatif-doktriner, berarti posisi hukum telah bergeser dari bagian keberagamaan menjadi agama yang bersifat ideal. Oleh sebagian umat Islam, posisi hukum Islam tersebut disejajarkan dengan mașādiral-sharī'ah, dan tidak ada peluang bagi pemikiran untuk mengembangkan atau menyesuaikan dengan dinamika masyarakat. Doktrin ini telah melahirkan wacana tertutupnya pintu ijtihad dan umat Islam cukup yakin bahwa produk hukum Islam telah sempurna dan mampu menyelesaikan permasalahan yang dihadapi. 
Ketika pemikiran tersebut demikian subur, maka hukum Islam ada dalam pergumulan wacana, kehilangan daya kekuatan ontologinya dan tidak mampu menghadirkan kemaslahatan. Dalam situasi demikian, para fuqahā' di Indonesia tidak memiliki kreatifitas dan keberanian untuk mengembangkan hukum Islam. Sebagian fuqah $\bar{a}^{\prime}$ menganggap ketentuanketentuan dalam hukum Islam sebagai ciptaan Allāh yang sakral dan manusia tidak berhak terlibat di dalamnya (Wahid, 2009: 123). Akibatnya umat Islam menenggelamkan diri dalam kesalehan individual dan asketis, sebagai ciri khas kehidupan dan pandangan mistisisme yang subur berkembang di Indonesia (Tebba, 2004: 112).

Pada saat sikap masyarakat memegangi hukum Islam sebagai normatif-doktriner, berkembang pendekatan empirisme dalam ilmu-ilmu sosial untuk memahami agama. Pendekatan empirisme untuk ilmu-ilmu sosial di Barat hanya mengakui pengetahuan yang dianggap ilmiah bila didasarkan pada pengalaman indrawi yang dapat diverifikasi secara obyektif (Muslih, 2004: 62). Pandangan ini kemudian dikebangkan lebih ketat oleh kaum positivis dan dijadikan basis bagi sains modern. Pada sisi lain, kalangan agamawan hanya mengakui pendekatan metaphisiktransendental untuk mengkaji dimensi spiritual agama dan hukum Islam. Para agamawan bahkan menuduh pendekatan positivisme sebagai pendekatan yang dapat merusak agama.

Melebih-lebihkan kualifikasi ilmiah dari pengalaman obyektif yang dapat diverifikasi secara indrawi dan sebaliknya kreteria kebenaran atas pengalaman spiritual dalam memahami agama, keduanya memiliki kelemahan dan kelebihan masing-masing. Karena pada kedua pengalaman memiliki dimensi obyektif dan subyektif, dan masing-masing entitas memiliki karakteristik yang tidak sama. Pemanfaatan pendekatan empirisme untuk memahami dimensi spiritualitas agama dan hukum Islam berdampak serius tergerusnya entitas dimensi tersebut, namun demikian dimensi empiris-praktis agama dan hukum Islam dengan kualifikasi obyektif-indrawi secara metodologis lebih tepat menggunakan pendekatan empirisme.

Pemanfaatan pendekatan empirisme dan metaphisiktransendentalisme secara gegabah untuk mengkaji agama dan ontologi hukum Islam terbukti membawa kekacauan berpikir dan bukan tidak mungkin akan terjadi reduksi spiritualitas beragama dan menipisnya iman (Muslih, 2004: vi). Dengan kata lain spiritualitas beragama dan iman bisa tergerus oleh pendekatan empirisme dengan kualifikasi kebenaran indrawi dan rasio. Esensi iman yang hanya bisa dijangkau oleh kebenaran transendental telah diposisikan sebagai tidak ilmiah dan tidakobyektif karena tidak bisa diverifikasi oleh pengalaman empiris manusia. 


\section{SIMPULAN}

Hasil kajian menunjukkan bahwa tashrī' hukum Islam bidang muamalah mengikuti perkembangan realitas sosial dan melangkah dalam dinamika tersebut, oleh karena itu membahas penerapan hukum Islam tidak bisa dilepaskan dari konsep dasar hukum Islam bidang muamalah, karakteristiknya, obyek forma hukum Islam bidang muamalah dan realitas sosial kemanusiaan. Perumusan dan pengembangan hukum Islam bidang muamalah ini harus sejalan dengan karakteristiknya dan terus dijaga agar tidak meninggalkan karakteristik tersebut. Jika perumusan dan pengembangan hukum Islam bidang muamalah meninggalkan karakteristiknya, tentu saja akan mengalami problematika serius dan bahkan akan ditinggalkan oleh para pemeluknya sendiri.

\section{DAFTAR PUSTAKA}

Abdullah, M. Amin, Studi Agama Normativitas atau Historisitas, Yogyakarta: Pustaka Pelajar, 1996.

Ali, Muhammad Daud, Hukum Islam: Pengantar IlmuHukum dan Tata Hukum Islam di Indonesia, Jakarta: Raja Grafindo Persada, 1999.

Auda, Jassir., Maqāşsid al-Sharī'ah as Philosophy of Islamic Law, LondonWashington: The IIT Press, 2008.

Ayyubi, Nazih, Political Islam: Religion and Politics in the Arab World, dalam Bahtiar Effendi dalam Din Syamsuddin, "Islam dan Politik Era Orde Baru”, Kata Pengantar Jakarta: Logos Wacana Ilmu, 2001.

Azra, Azyumardi, PergolakanPolitik Islam, Jakarta: Paramadina, 1996.

Beilharz, Peter, Teori-Teori social Observasi Kritis Terhadap Para Filosof Terkemuka, Yogyakarta: Pustaka Pelajar, 2003.

Coulson, Noel. J., The History of Islamic Law, Inggris: Edinburg University Press, 1964.

Djamil, Fathurrahman, Filsafat Hukum Islam, Jakarta: Logos WacanaIlmu, 1997.

D. Hendropuspito, O.C., Sosiologi Agama, Yogyakarta: Kanisius \& BPK GunungMulia., 2000.

Fazlurrahman, Tema Pokok Al-Qur'an, Cet. Ke-1, Bandung: Pustaka Perpustakaan Salman ITB, 1983.

Ghofur, Abdul, Demokratisasi dan ProspekHukum Islam di Indonesia, Yogyakarta: PustakaPelajar, 2002.

Halim, Abdul, Politik Hukum Islam di In donesia, Cet. Ke-1, Jakarta: Badan Litbang \& Diklat Departemen Agama, 2008. 
Mudzhar, HM., Atho, Pendekatan Studi Islam dalam Teori dan Praktek, Yogyakarta: Pustaka Pelajar, 1996.

Muhadjir, H. Noeng, Metodologi Penelitian Kualitatif, Yogyakarta: Rekasarasin, 1996.

-----------, Metodologi Keilmuan Paradigma Kualitatif, Kuantitatif, dan Mixed, Yogyakarta: Rake Sarasin, 2007.

Muslih, Muhammad, Filsafat Ilmu Kajian atas Asumsi Dasar, Paradigma dan Kerangka Teori Ilmu Pengetahuan, Yogyakarta: Belukar, 2004.

Parson, Talcot, The social System, New York: The Free Press, 1996.

Rahman, Fazlur, Islam, Chicago and London: University of Chicago Press, 1979.

Robertson, Roland (ed), Sociology of Religion, alih bahasa oleh ahmad Fedyani S. "Agama dalam Analisa dan Interpretasi Sosiologi", Jakarta: Rajawali Press, 1992.

Ritzer, George, Sociology: A Multiple Paradigm science, alih bahasa oleh Ali Mandan "Sosiologi: Ilmu Pengetahuan Berparadigma Ganda", Jakarta: Rajawali Press, 1992.

Sahradi, Jamali, Metodologi Studi Islam Menelusuri Jejak Historis Kajian Islam ala Sarjana Orientalis, Bandung: Pustaka Setia, 2008.

Schacht, Joseph, An Introduction to Islamic Law, London: Oxford University Press, 1969.

Saleh, Abdul Mun'im, Hukum Manusia Sebagai Hukum Tuhan, Yogyakarta: Pustaka Pelajar, 2009.

Syah, Ismail Muhammad, Filsafat Hukum Islam, Jakarta: BumiAksara, 2009.

Tafsir, Ahmad., Filsafat Umum Akal dan Hati sejak Thales sampai James, Bandung: Remaja Rosdakarya, 1992.

Tebba, Sudirman, Sosiologi Hukum Islam, Yogyakarta: UII Press, 2003.

Zuhailī, Wahbah, al-Fiqh al-Islāmī, Vol. 1, Damaskus: Dār al-Fikr, 2008. 
Muhaimin

Halaman ini sengaja dikosongkan 